\title{
COMPARISON OF CUSTOMER ATTITUDES TOWARDS LOYALTY PROGRAMS IN PRAGUE AND IN LONDON
}

\author{
Tahal, R.
}

Loyalty programs rank among the most important marketing tools used for motivating customers in repeated purchases. The history is more than a hundred years old and there are many interesting points in the development. At present, programs can be built on the basis of various algorithms. In any case, it is necessary to develop such programs that are positively accepted by customers, viewed as useful, creating emotional ties to a retailer or to a brand. This study is based on primary data collected in the Czech Republic and in Great Britain, and it aims at two research targets. The first is to compare customers' preferences in choosing loyalty programs in the two countries, to find similarities and differences. The second target is to make a comparison of customers' willingness in disclosing their personal data for a retailer when signing up for a loyalty program.

Keywords: Loyalty; loyalty scheme; personal data; market research; consumer JEL classification: M31

\section{Introduction}

Loyalty programs belong among the marketing tools that facilitate not only rewarding current customers, but even gaining credibility among potential customers. In the communication mix, loyalty programs amount to classical instruments for supporting the sale. Unlike other sale-supporting tools, such as discount promotions, coupons, free samples, games and lotteries, bonuses, giveaways, all of them with a short-time focus, loyalty programs concentrate on building long-time relations with customers. It is highly important for companies to retain the existing customers; gaining new ones can be as much as five times more expensive (Kotler, Keller, 2007).

Loyalty programs also provide companies with information about purchasing behavior of particular customers. The information can further be used for communication based on the segmentation into various customer groups or even for individual communication.

There is a comparatively long history of loyalty programs, dating back to the late $18^{\text {th }}$ century when American retailers started to reward their customers with copper tokens that were exchanged for goods when making their next purchase. The retailers soon understood that the production of the tokens was expensive, and at the end of $19^{\text {th }}$ century, the tokens were consequently replaced with paper marks that could be redeemed by customers for products chosen in a gift catalogue. About another hundred years later, around the 1990s, loyalty programs appeared approximately in the shape known 
at present - the programs, often card based, were designed individually by retailers, the identification of the customers participating in a program and the registration of purchases and rewards were performed in an electronic way, based on the ownership of a chip or a plastic identification card.

The value of a loyalty program in customers' minds is determined by several parameters (see e.g. Pelsmacker et al., 2003), usually including:

- Total monetary value of the program for the user,

- the number (frequency) of the possibilities for gaining a reward,

- the relevance degree of rewards for the customer,

- comfort.

A loyalty program can be successful if it provides sufficient aspiration benefit, i.e. if the individual customer estimates the advantage of the program to be higher than certain limitations on time and privacy caused by participating in the program.

\section{Literature Review}

Keeping in mind the importance of loyalty programs, companies try to influence customers across their lifecycles through adequate acquisition and development strategies. (MeyerWaarden, 2007, p. 224). Within the framework of existing program varieties throughout the world, customers are offered incentives which differ and depend on the type of the program and marketing strategy of a company. Although the loyalty programs are considered to be effective marketing tools, some authors point out that if the customers' loyalty to the selling company is based on elements inextricably linked to a specific loyalty program, then "loyalty" should fade when the program is no longer attractive (see e.g. Evanschitzky et al., 2012, p. 626). That's why it is essential to keep monitoring the efficiency, so as to find out if a loyalty program is not only an administrative ballast for a company.

There are retailers who develop loyalty programs with inclusion of measures for preventing customers from falling away.

Some authors (e.g. Nunes and Drèze, 2006) develop this idea and they back up the importance of an efficiently constructed loyalty algorithm by stating that "First, it is unclear if a customer will stay loyal after claiming the free unit after $n$ purchases. Second, the retailer will lose the entire margin of the free unit, especially when the free item is a commonly purchased item at regular price Third, if $n$ is a low number, then the retailer incurs a significant cost by giving away too many free units. If $n$ is a large number, then customers may get discouraged."

In order to complete the description of the purpose of loyalty programs, it is worth mentioning that certain types of companies, especially airlines and banks, base their loyalty programs on the so-called status (representing a certain comfort or service level) offered to the customer. Those customers whose spending during a specific time period exceeds a preset threshold then earn preferred status, though they often must purchase full price or unpromoted fares to earn these credits (Mathies and Gudergan, 2012, p.275).

An important factor is what identification information, if any, is required when registering for a program and what information the customer is willing to impart. Supermarket cards represent a challenge for privacy educators, in part because they are 
presented to customers as merely "savings cards" that "reward customers" with lower prices or discounts (Albrecht, 2006, p.9). Of course, plenty of customers object to being monitored by retail giants. Surely many people are less likely to support their local bookshop if they felt the bookseller was gathering a dossier on them (O'Connell, 2013).

It should also be mentioned that loyalty programs are used especially in the product categories where goods are bought more frequently. Fast moving consumer goods (FMCG) are purchased repeatedly, with a relatively high frequency. This allows consumers to develop expertise in their purchases (Srivastava and Sharma, 2013, p. 178).

\section{Research Questions}

This paper presents the continuation of the author's research into loyalty programs, the focus being widened to the international level. The study is based on a particular research project carried out in the Czech Republic (Prague) and in Great Britain (London).

Two research questions were formulated:

RQ1: What kind of rewards do consumers prefer and what is important for them when they enter loyalty programs?

RQ2: What personal information are consumers willing to provide when signing up for loyalty programs?

The aim is to assemble the results of comparable research in the two countries and to find out similarities and differences in the customers' opinions.

\section{Data and Methods}

The data collection was performed in the same way in Prague as in London. The sample was arranged so that it should be a representative choice of the population according to age (15+) and gender. The proportional numbers for each city were based on statistical information about the population structure published by the Czech Statistical Office in Prague and the Office for National Statistics in Great Britain.

Table 1 | Data collection details

\begin{tabular}{|l|l|}
\hline Characteristic & Survey value/description \\
\hline Population & Population of Prague and London, age 15+ \\
\hline Sampling method & quota sampling \\
\hline Sample size & 335 respondents in Prague, 323 respondents in London \\
\hline Sampling date/period & April 2015 \\
\hline Survey method & $\begin{array}{l}\text { Combination of personal and on-line data collection. } \\
\text { Data gathered by a research team at the University of Economics, Prague }\end{array}$ \\
\hline
\end{tabular}

Source: author 
For answering the research questions, a four-degree Likert scale was used in order to record the intensity of the respondents' approval or disapproval ("YES", "More likely YES", "More likely NO", "NO").

The respondents' answers were transformed into binary variables: ONE for those who reported pure "YES" and "More likely YES" on the Likert scale, and ZERO for those who reported "NO" and "More likely NO" on the Likert scale. In addition to the comprehensive presentation of the results, the data were analyzed by means of the chi square test.

For answering research question 1, loyalty programs were divided into the following categories according to the way of rewarding the customer:

- Percentage discount on total purchase.

- Percentage discount on specified goods / brand.

- Discount on total purchase expressed in CZK/£.

- Discount on certain goods expressed in $\mathrm{CZK} / £$.

- Material rewards (gifts).

- Intangible rewards (wellness stays, adventure packages).

- Percentage discounts at partners' stores.

When answering research question 2, the respondents were asked about their willingness to provide a company with the following personal information when entering a loyalty program:

- Name and surname,

- address,

- date of birth,

- gender,

- e-mail,

- phone number,

- interests and hobbies.

For the purpose of correct statistical evaluations, as well as for comparing the research outcomes from the two localities, the answer rates on each degree of the Likert scale were reduced to a common denominator, so as to compensate for slightly different values of the samples in Prague and London.

A statistical significance test was carried out as well, using the chi-square method. The data were compared as to the frequency of positive and negative answers in the two localities, based on the following test statistic:

$$
\chi^{2}=\frac{\sum(O-E)}{E}
$$

where $O$ is the observed frequencies and $E$ is the expected frequencies.

The frequency of the answers "YES+More likely YES" vs. "NO+More likely NO" in Prague and in London were compared for each of the mentioned items.

\section{Results}

Initially, we focused on the respondents' answers concerning the first research question. The following table shows the total representation of the "YES" and "More likely YES" answers (after the transformation into binary variables equal to the value "1"). 
Table 2 | Loyalty scheme preferences

\begin{tabular}{|l|c|c|c|}
\hline Type of loyalty scheme & $\begin{array}{c}\text { \% of “YES” + “More } \\
\text { likely YES" answers } \\
\text { in Prague* }\end{array}$ & $\begin{array}{c}\text { \% of “YES” + “More } \\
\text { likely YES" answers } \\
\text { in London* }\end{array}$ & $\begin{array}{c}\text { Positive/negative } \\
\text { ratio** }\end{array}$ \\
\hline $\begin{array}{l}\text { Percentage discount on total } \\
\text { purchase }\end{array}$ & $77 \%$ & $79 \%$ & 0.03 \\
\hline $\begin{array}{l}\text { Percentage discount on } \\
\text { specified goods / brand }\end{array}$ & $71 \%$ & $55 \%$ & -0.22 \\
\hline $\begin{array}{l}\text { Discount on total purchase } \\
\text { expressed in } £\end{array}$ & $69 \%$ & $77 \%$ & 0.12 \\
\hline $\begin{array}{l}\text { Discount on certain goods } \\
\text { expressed in } £\end{array}$ & $67 \%$ & $64 \%$ & -0.04 \\
\hline Material rewards (gifts) & $23 \%$ & $40 \%$ & 0.73 \\
\hline $\begin{array}{l}\text { Percentage discounts at } \\
\text { partner's stores }\end{array}$ & $24 \%$ & $37 \%$ & 0.59 \\
\hline $\begin{array}{l}\text { Intangible rewards (wellness } \\
\text { stays, adventure packages) }\end{array}$ & $14 \%$ & $27 \%$ & 0.92 \\
\hline
\end{tabular}

Note: * Based on the total number of respondents in the respective research locality.

** The ratio was calculated on the base of those respondents who chose the answers "YES" or "More likely YES" for a given option in the loyalty program. A positive number indicates higher occurrence of positive answers in London, contrary to a negative number (after recalculating to equal size of the samples).

Source: author

The table presents the types of loyalty programs in decreasing order according to the frequency of positive answers in Prague.

So as to enable comparisons of the consumer behavior in the two research localities, the same algorithm was also used for answering the second research question.

Table 3 | Willingness to provide personal information

\begin{tabular}{|l|c|c|c|}
\hline $\begin{array}{c}\text { Type of personal } \\
\text { information }\end{array}$ & $\begin{array}{c}\text { \% of "YES" + "More } \\
\text { likely YES" answers in } \\
\text { Prague* }\end{array}$ & $\begin{array}{c}\text { \% of "YES" + “More } \\
\text { likely YES" answers in } \\
\text { London* }\end{array}$ & $\begin{array}{c}\text { Positive/ } \\
\text { negative ratio }\end{array}$ \\
\hline Name and surname & $77 \%$ & $85 \%$ & 0.11 \\
\hline Gender & $76 \%$ & $81 \%$ & 0.07 \\
\hline Address & $60 \%$ & $73 \%$ & 0.22 \\
\hline E-mail & $55 \%$ & $71 \%$ & 0.29 \\
\hline Interests and hobbies & $49 \%$ & $46 \%$ & -0.06 \\
\hline Date of birth & $38 \%$ & $67 \%$ & 0.76 \\
\hline Phone number & $28 \%$ & $34 \%$ & 0.23 \\
\hline
\end{tabular}

Source: author 
Even in this table the items are arranged decreasingly according to the frequency of positive answers by respondents in Prague.

The numbers obtained in the research indicate higher willingness of the English customers to disclose their personal and identification data for use in a loyalty program. The average percent expressing the willingness in all the observed categories is $55 \%$ for the Czech Republic (Prague) and 65\% for England (London).

As the obtained data are intended both for practical use and as a theoretical background for prospective follow-up studies, a statistical significance test was carried out as well. It can be concluded that the test has unambiguous results, with the statistically relevant difference at $\alpha=0.05$ in all the cases.

\section{Practical Implications}

Companies often presume that a loyalty program should impel the customers to make purchases repeatedly for a long time, collecting a certain number of points, and only after a specified period, sometimes as long as a whole year, can the customer be rewarded. Such an approach may often result in quite a contrary effect of losing attractiveness for a customer, the company paying the costs of the program, without getting any final positive effect.

This study tries to put forward a kind of mirror view, analyzing the popularity of loyalty schemes as seen by the customer. The fact is that some retailers use loyalty programs not only for the primary purpose, but in this way they collect demographic and contact data for their own CRM databases. Such topics may be delicate and it is necessary to know in what degree the customers are willing to reveal their personal and identification data.

The research into customers' behavior in various countries and in differing cultural surroundings seems to be profitable especially for global companies with branches in many countries in Europe and in other continents. The companies sometimes apply identical marketing schemes in more countries. Undoubtedly, this is convenient from the viewpoint of the effective administration of IT systems, but the opinions and attitudes of customers may differ even in geographically close countries.

A suitably constructed and assembled loyalty program is a convenient marketing tool, favorable for brands and retailers in retaining current customers and consequently in increasing profitability. Preceding studies (see e.g. Tahal, Stř́iteský, 2014), however, point out that some companies use such algorithms that are no longer attractive for customers. We can frequently find too sophisticated programs with incomprehensible underlying algorithms.

Our studies show that an efficient loyalty program should be constructed in a simple way, offering the customer to reach the reward within a short time span, the prize being either immediate discount on the purchased goods or a gift complementary to the purchased items, and thus being really useful for the customer.

\section{Conclusions}

The study deals with two research questions. The answers concerning the first question, i.e. "What kind of rewards do people prefer and what is important for customers when entering loyalty programs" can be interpreted in two ways: 
1) Both the Czechs and the English evidently prefer such types of loyalty programs that are based on an immediate financial discount on the total purchase, or price deduction on certain items. In a similar way, customers in both countries are less interested in loyalty programs based on a specific reward (a material present) and intangible rewards (wellness stays, adventure packages). The customers are less interested even in programs consisting of the possibilities of being offered benefits at a company's business partners.

2) On the other hand, it can be clearly traced that the differences in preferring various types of loyalty programs are less conspicuous with the English than with the Czechs. Specific gifts, discounts in partnership shops, or various vouchers are less attractive for Czech customers; the ratio for such benefits among English customers is 59 - 73\% higher.

When looking for the answers to the second question, the research revealed that English customers are more willing to provide their personal data when registering for a loyalty program. Generally, it is not surprising that customers understand the necessity of giving away their names and basic contacts, but from the marketing viewpoint it is interesting that English customers disclose the birth date more easily than Czech customers do, and on the contrary, the English are less willing to mention their points of interest and hobbies. It is just the individual's interests and hobbies that proved to be the only information that the Czech customers are more willing to talk about, compared to the English.

\section{References}

Albrecht, K. (2006). Supermarket" Loyalty" Cards and Consumer Privacy Education: An Examination into Consumer Knowledge about Cards' Data Collection Function. Doctoral dissertation. Harvard Graduate School of Education.

Evanschitzky, H., Ramaseshan, B., Woisetschläger, D. M., Richelsen, V., Blut, M., \& Backhaus, C. (2012). Consequences of customer loyalty to the loyalty program and to the company. Journal of the Academy of Marketing Science, 40(5), 625-638.

Ho, R., Huang, L., Huang, S., Lee, T., Rosten, A., \& Tang, C. S. (2009). An approach to develop effective customer loyalty programs: The VIP program at T\&T Supermarkets Inc. Managing Service Quality: An International Journal, 19(6), 702-720.

Kotler, P., \& Keller, K. L. (2007). Marketing management. $12^{\text {th }}$ edition. Prague: Grada.

Mathies, C., \& Gudergan, S. P. (2012). Do status levels in loyalty programs change customers' willingness to pay?. Journal of Revenue \& Pricing Management, 11(3), 274-288.

Meyer-Waarden, L. (2007). The effects of loyalty programs on customer lifetime duration and share of wallet. Journal of Retailing, 83(2), 223-236.

Nunes, J. C., \& Drèze, X. (2006). Your loyalty program is betraying you. Harvard business review, 84(4), 124.

O'Connell, J. (2013). Money: Team high street fights back: Shopping multi-store discount cards and community loyalty schemes are among the weapons being used by local independent stores to stay alive. Joanne O'Connell reports. The Guardian.

Pelsmacker, P., Geuens, M., \& van der Bergh, J. (2003) Marketing Communications. Prague: Grada. 
Srivastava, K., \& Sharma, N. K. (2013). Consumer attitude towards brand extension:

A comparative study of fast moving consumer goods, durable goods and services. Journal of Indian Business Research, 5(3), 177-197.

Tahal, R., \& Stříteský, V. (2014). Loyalty Programmes and Their Perception by Customers and Operators of Retail E-shops. Acta Oeconomica Pragensia. 22(4), 30-41.

\section{Author}

\section{Mgr. Radek Tahal, Ph.D.}

Assistant Professor

Department of Marketing

Faculty of Business Administration

University of Economics, Prague

W. Churchill Sq. 4, 13067 Prague, Czech Republic

radek.tahal@vse.cz 